\title{
Islamic Capital Market for Social Development: Innovating Waqf Mobile Sukuk in Sub-Saharan Africa
}

\author{
Samsad Jahan
}

Aishath Muneeza

Siti Hajar Baharuddin

\author{
International Centre for Education in Islamic Finance (INCEIF), \\ Malaysia
}

\begin{abstract}
The use of sukuk in social development is an under-researched area, especially in the context of Sub-Saharan Africa. Although the Kenyan government has issued the world's first mobile bond and the Indonesian government has used mobile platforms as a distribution channels for the issuances of retail sukuk, little is known about mobile $s u k u k$ and its potential from the perspective Islamic social finance. This paper aims to explore the opportunities and challenges of mobile sukuk for social development, namely perpetual waqf mobile sukuk, where the concept of waqf is combined with qard. It is anticipated that the proposed type of sukuk has the potential to be used as an Islamic social finance instrument.
\end{abstract}

Keywords: Islamic Social Finance, Mobile Sukuk, Qard, Social Development, Waqf 


\section{Introduction}

In recent times, financial inclusion has been salient reform agenda in most countries. The developing countries predominantly envision financial inclusion for poverty reduction and opportunities for economic expansion. The World Bank Group (2021) defined financial inclusion as "individuals and businesses have access to useful and affordable financial products and services that meet their needs - transactions, payments, savings, credit and insurance - delivered in a responsible and sustainable way". Accordingly, major efforts have been carried out to harmonise the banking and financial institutions towards the target state including mobile money development. The perceptually rapid penetration of mobile money in Sub-Saharan Africa (SSA) has successfully brought low-income people into the basic banking ecosystem (DemirgucKunt et al., 2018). However, the uptake of capital market products like stocks and sukuk remains low with the absence of a strong retail investor base. Sukuk is known as instrument of the Islamic capital market mainly targeting for corporate sector and high net wealth individuals. Although the idea of selling mobile sukuk is relatively new, selling government bonds via mobile phone is not new as the Kenyan government launched a retail bond to raise funds for building infrastructure in 2017 (Kacungira, 2017). Thus, this research seeks to adopt an innovation of mobile sukuk that can assist retail investors to gain access to investment products and assist in social and economic development.

This paper is structured as follows. The first section covers the introduction, followed by focus on literature review and the application of conventional mobile bond, then social finance and capital market. The following section focuses on proposed mobile sukuk structure including strength and weaknesses, while the last section concludes the research. The analysis of this paper is based on a review of relevant literature, ranging from academic studies, industry reports, and government statistics.

\section{Literature Review}

A number of studies have critically demonstrated the development of mobile phone in Sub-Saharan Africa (Demirguc-Kunt et al., 2018; Hughes and Lonie, 2007; Klapper and Singer, 2017; Riley and Kulathunga, 2017). Mobile technology has slowly but noticeably transformed domestic remittances in the region which will be discussed in further details in this section.

\subsection{Mobile Phone Development}

Mobile financial services are among the most favourable mobile applications in the developing world. To date, innovations of mobile money leverage rapidly expanding mobile phone access in Sub-Saharan Africa to support banking and payment services (Demirguc-Kunt et al., 2018). Despite the fact that they might not have access to smartphone and internet, mobile phone users can use the basic features of mobile phones namely USSD and SMS to transfer, save, and borrow money.

\subsubsection{Mobile Phone for Domestic Remittances}

M-PESA, the leading local mobile money transfer service, is a widely known mobile money platform for providing basic financial services for the unbanked populations in

International Journal of Management and Applied Research, 2021, Vol. 8, No. 2 
Africa (Bongomin et al., 2018; Donner and Tellez, 2008; Riley and Kulathunga, 2017). Provided by the Safaricom of Kenya, M-PESA has reached a substantial size unbanked individuals to date. Piper (2000) reported that 72 percent of Kenyans have a mobile money account. Before the launch of M-PESA, only 18.5 per cent of Kenyans used formal services like bank accounts, 8.1 per cent used semi-formal services (for example those provided by microfinance institutions), 35.0 per cent used the informal sector, and at least 38.3 per cent were entirely excluded from these (Van Hove and Dubus, 2019). Earlier adoption of M-PESA was restricted only to cash-in or cash-out services via "cash merchants" or agents who go on to act like human automated teller machine (ATM) (Donovan, 2012). Today, people can use mobile money for buying groceries or paying for utilities (Piper, 2020).

Mobile payment services for the unbanked populations allow users to transfer money securely, instantly, and directly to another users (Hughes and Lonie, 2007). The high density of the agents, the service accessibility to almost every mobile phones in Kenya as well as the increasing demand for financial services itself all contributed to the success of M-PESA (Aker and Mbiti, 2010; Hughes and Lonie, 2007; Klapper and Singer, 2017; Piper, 2020; Riley and Kulathunga, 2017). The appropriate pricing strategy and Safaricom's good relationship with Central Bank of Kenya also contributed to this success story but the significant factor here is the simplicity of text messaging requiring no smartphones or apps which is a crucial aspect for poor families providing them the safety net of option to save money and receive money transfers from friends and family (Piper, 2020). In addition to money transfer, the usage of mobile money has also promoted saving and borrowing (Hughes and Lonie, 2007; Klapper and Singer, 2017; Riley and Kulathunga, 2017).

\subsubsection{Mobile Phone for Payment and Other Services}

In Kenya, the application of mobile money account evolved from only domestic remittances, purposes up to diverse functions including saving, credit services and cross border payment (Riley and Kulathunga, 2017). A research by Demirguc-Kunt et al (2018) showed that the long-term saving behaviours in developing countries include alternative saving semi-formally by using a savings club, investing in jewellery and real estate as well as saving in cash at home. Such informal ways of saving have drawbacks such as theft or fire danger. Financial innovation namely mobile money services not only allow users to send and receive money but also encourage savings (Jack and Suri, 2014; Blumenstock et al., 2015; Riley and Kulathunga, 2017). For instance, M-PESA has become a savings instrument for Kenyans.

\subsubsection{Mobile Phone and Financial Inclusion}

Financial inclusion can be broadly defined as access to and usage of appropriate, affordable, and accessible financial services (Klapper and Singer, 2014). The inclusive financial services play vital roles in reducing impoverishment, enhancing shared prosperity, and endorsing wide-ranging economic growth and development (Demirguc-Kunt et al., 2018). Inaccessibility to finance in the digital world is likely to have more negative consequences than in past (Hughes and Lonie, 2007). Today, the continued evolution of financial inclusion driven by mobile phone is clearly seen in Sub-Saharan Africa with 21 percent of adults in the region having a mobile money account (Demirguc-Kunt et al., 2018). When compared to the US where 93.1 percent

International Journal of Management and Applied Research, 2021, Vol. 8, No. 2 
of the population had an account at a formal financial institution in 2017, there were only 55.7 per cent of Kenyans over 15 had an account at a formal financial institution (Van Hove and Dubus, 2019). Haftu (2019) showed that growth in mobile phone penetration has contributed significantly to the GDP per capita of the region, based on a panel data of 40 countries for the period of 2006-2015 where a $10 \%$ increase in mobile phone adoption leads to a 1.2 percent rise in GDP per capita.

\subsection{Conventional Mobile Bond}

Notwithstanding with earlier contributions, there is wide-ranging demand in the region for many other financial services that are underdeveloped, such as the provision of several types of credit services, cross border payments, insurance services as well as various forms of investment products (Sy et al., 2019), thus being socially concerned M-Akiba was introduced on 30th June 2017. With the "Save Money. Make Money. Build Kenya" slogan, M-Akiba aims to raise funds to finance infrastructure projects via mobile phones. M-Akiba is a three-year bond with a tax-free ten percent coupon paid semi-annually, giving retail investors an alternative to low-interest earning accounts in conventional banks or mobile wallets (Kacungira, 2017). Retail investors may use their mobile phones to create security accounts, buy securities, receive monthly interest/coupons, and exchange them in the secondary market, making the entire process significantly easier (Cook and Osano, 2018).

\subsubsection{History of conventional Mobile Bond}

Having the initial plan to sell Kenyan government investments via cell phone, the emergence occurred under the supervision of the National Treasury and the Central Bank of Kenya (Cook and Osano, 2018) then the Kenyan government then issued this bond through the Central Bank of Kenya (CBK) in cooperation with the Nairobi Securities Exchange (NSE) and the Central Depository Settlement Corporation (CDSC), Mobile Network Operators, and Kenya Association of Stockbrokers \& Investment Banks (KASIB) (M AKIBA, 2017). As per M AKIBA's website (2017) for this mobile bond initial minimum investment amount per account is Kenyan Shillings 3,000 ( USD 30), with consecutive trades in multiples of Kenyan Shillings 500 ( USD 5). An investor, who wishes to buy or trade in any Kenyan Government securities, is required to open a Central Depository System (CDS) account with the Central Bank of Kenya, which can be opened directly with the Central Bank. As defined by Bursa Malaysia, "the Central Depository System (CDS) acts as a means of representing ownership and movement of securities where CDS account holders not only enjoy the conveniences in obtaining electronic securities transfer and trade settlement", but they can also open an account through an authorized agent, which includes commercial banks, investment banks, stockbrokers, and investment consultants (M-Akiba, 2017). Their official website also points out the significant difference that normally it takes two days to acquire a government bond, as opposed to M- Akiba's quick process.

This mobile bond provides regular individuals with access to the nation's capital market, with the goal of broadening the government's investor base and lowering borrowing costs. Cook and Osano (2018) state that prior to M-Akiba, the minimum investment amount for a bond was Kenyan Shillings 50,000 (about US\$500) and opening an investing account was a time-consuming procedure. They further

International Journal of Management and Applied Research, 2021, Vol. 8, No. 2 
mentioned that there were barely 10,000 individual investors in government bonds, accounting for approximately $2 \%$ of total bond holdings, whereas M-Akiba could reach more than 30 million registered mobile money account holders. Some important facts mentioned in M-Akiba's official website (2017) that for many years individual Kenyan investors did not get a chance to make money from bonds, as a result, they were not participating in raising funds for nation building. M-Akiba opened that prospect to these retail investors, which was targeted only towards foreigners and local institutional investors prior to that and therefore resulted in $98 \%$ uptake in government bonds by foreigners and local institutional investors, with only two percent by individual investors (M-Akiba, 2017).

The official website further points out other reasons for the bond issue which are discussed in this paragraph. One reason is enhancement of financial inclusion for economic development through this issuance of retail infrastructure bond. The fund raised is being utilized for government infrastructural development projects. Furthermore, the government aimed to improve the savings and investment culture with the M-Akiba bond. Kenyan savings account for $11 \%$ of GDP, while countries such as Qatar account for 60\%, and Rwanda and Uganda account for $22 \%$ apiece. The government also evaluated M-Akiba's long-term influence on driving down Government borrowing rates, which would allow infrastructure and development projects to be executed at cheaper prices because the cost of finance for these projects will decrease as borrowing rates fall (M-Akiba, 2017).

\subsubsection{Acceptance and Impact of the Innovation}

Kenya's first mobile-only government bond fell short of its goal. The Kenyan government was initially making a limited offer of 150 million shillings to test the market attractiveness of M-Akiba (Kacungira, 2017). Despite the fact that over 300,000 individuals registered on the M-Akiba platform, only 5,988 acquired M-Akiba bonds at the official launch (Cook and Osano, 2018). A report made by Financial Sector Deepening (FSD) Kenya summarised the following reasons for the low uptake on M-Akiba: poor timing, poor understanding of product, confusing purchase process, lack of prompts or reminders, agents' lack of encouragement to actually invest after registering, weak customer care practices, concerns about minimum investment (Cook and Osano, 2018).

However, M-Akiba receives recognition overseas. Inspired by the introduction of MAkiba in Kenya, Indonesia began selling sukuk online, expanding its distribution channels to include mobile platform as well as peer-to-peer financing platforms (Tan, 2018).

\section{Social Finance and Capital Market}

Social finance is a method of managing money that provides both a social benefit and a monetary benefit. Sarah Dadush (2015) pointed out social finance could become a mainstream source of funding for goods and services aimed at disadvantaged people all around the world. She further stated that impact investors use social finance to put their money behind businesses that provide vital products and services to underrepresented people while still making a profit. The operation at the intersection of commerce and philanthropy is bound by impact investors and social businesses,

International Journal of Management and Applied Research, 2021, Vol. 8, No. 2 
who want to generate financial return in conjunction with a positive social impact (Dadush, 2015). Social finance seeks to rectify problems that are caused or intensified by market exclusion while exploiting the tremendous market opportunities (Dadush, 2015). Islamic Financial Institutions (IFIs) are meant to be socially responsible for two interrelated reasons: their status as a financial institution conforms to a collective religious obligation and their exemplary position as a financial intermediary (Farook, et al., 2011). IFIs which actively participate in CSR activities and demonstrated transparency in reporting are more likely to gain customers' trust, satisfaction, and loyalty (Muflih, 2021). It is worth emphasizing that Islam does not discourage the pursuit of profit, but not at the expense of other key stakeholders (Adnan Khurshid et al., 2014).

Many Muslim-populated countries are struggling with clean water and sanitation, affordable energy, infrastructure, and shelter. Islamic finance has scope to create impact through innovative instruments like waqf sukuk, SRI sukuk, green sukuk and infrastructure sukuk taking initiatives considering Islamic finance solutions to close the gap in social development and relief efforts. As highlighted by OECD (2020), Arab donors could consider using Islamic finance as a means to strengthen partnerships with Muslims-majority developing countries. Contributions should be increased toward a more united strategy to close the global income inequality gap and transitioning to a human excellence rather than human survival.

There is a scope for financial innovation to create market-based solutions to mobilise investments in technology and projects that promote sustainable and inclusive economic and social development, thus there is enormous probability to expand the role of the capital market in developing innovative approaches to finance environmental, social, and sustainable development projects.

\subsection{Waqf as a Social Finance Tool}

When we focus on the social finance side of Islamic Economic System, it is worth discussing waqf. Waqf is a charitable endowment under Shariah law, which typically involves donating a plot of land, a building, or even livestock for Muslim religious or charitable purposes without any intention of reclaiming the assets (Mar Iman and Mohammed, 2020; Mohsin, 2020; Shukri et al., 2019).

Shaikh et al. (2017) pointed out that waqf can be formed in the modern context by devoting real estate, furniture or fittings, other moveable goods, and liquid forms of money and wealth such as cash and shares which can be compared to zakah and focus on one of the most essential characteristics of waqf that there is flexibility on which funds can be used. If waqf is permissible regarding modern-day property like cash and shares, the scope of involvement and benefit might get widen being elastic. The majority of impoverished people in developing nations do not have access to financial services, either because of supply-side sluggishness or a lack of supporting services (Shaikh et al., 2017). In war-torn places like Marawi city could be rebuilt or perhaps benefitted by the issuance of waqf sukuk, as suggested by Shukri et al. (2019).

\section{Proposed Waqf Mobile Sukuk}

Sukuk has emerged as a prominent tool used by governments and corporations around the world to (1) finance their needs and (2) diversify their funding pool in supporting

International Journal of Management and Applied Research, 2021, Vol. 8, No. 2 
economic and infrastructure development, especially in Islamic countries where economic activity is responsive to religious values (Agha, 2018). There are diverse types of sukuk invented, proposed, and implemented in the global economy. For example, waqf sukuk, sustainable and responsible investment (SRI) sukuk, green sukuk, sovereign sukuk, mobile sukuk are some of them. Through mobile sukuk a huge market can be reached which is not reached by banks, that market which has little or no access to internet, do not possess smart phone and does not have a bank account. Sub-Saharan Africa has many factors to deal with like electricity, education, clean water, healthcare, and many more. This proposed structure of waqf mobile sukuk as a financial instrument is designed in a way targeting social and economic development. These mobile users have less access to internet, having bank accounts troublesome to them. Social development tool like qard or waqf is not handy or promoted to them thus there is scope of touching a new target market through innovation or modifying existing tools.

\subsection{Modus Operandi}

Based on the concept of mobile technology, the proposed mobile sukuk allows potential buyers to buy sukuk without going to financial institutions to open a bank account. Moreover, the concept of waqf will be added in the whole mechanism of the proposed mobile sukuk.

The important set-up steps can be stated as the National Treasury will issue the sukuk through the Central Bank of a country, the capital markets authority will provide regulatory oversight, the Central Depository and Settlement Corporation (CDSC) of a country will manage the register of sukuk holders as well as principal redemption with delegated authority from the Central Bank. Mobile Money will be integrated with their USSD channels (e.g. *999\#) and payments capability will be added to the platform allowing consumers to open accounts, purchase sukuk and redeem. There will be a transaction limit as well as a daily transaction restriction. The Securities Exchange will allow sukuk online trading through its system and give customer care assistance via a hotline. To ensure a fair and transparent procurement process, a financial institution will be chosen as a market maker through a competitive bid procedure. In short, to invest, a small investor will simply register by pressing *999\# for example (USSD code) and following the steps which will not require a smartphone. As it is a social sukuk, there is no need of periodic payment disbursement but in case investors want principal back (initial investment), they can just sell it to another investor with the face value as the sukuk is tradable on the secondary market without any increase or decrease of the initial price.

The proposed model uses shari'ah compliant mechanisms of sukuk, waqf and mobile money. As can be seen in figure 1, this sukuk is based on qard between the obligor and the small investors. The government will form a Special Purpose Vehicle (SPV) which is a subsidiary created to isolate financial risk. This SPV will issue the sukuk to fund different social projects to economic growth, empowerment, and self-sustainability within border. The sukuk holders are the investors of those projects and the government will act as obligor. This waqf mobile sukuk will have a face value which will stay as it is without increasing or decreasing and will be paid by the retail investors as a crowd. Since the sukuk is based on waqf simply means that whatever is received as return from the sukuk investment after deducting the principal amount

International Journal of Management and Applied Research, 2021, Vol. 8, No. 2 
invested by the sukuk holders will be reinvested in the projects tagged with that specific sukuk. There are both principal return, and social return in proposed embedded structure whereby the sukuk holders will get the satisfaction of utilizing their money for social development of the nation and at the same time they are the beneficiaries of the successful sukuk projects.

For example, a given government believes that it is necessary to develop hospital for a village community but there has been a lack of funding to do so. The government could become the obligor and the issuer to issue the proposed waqf mobile sukuk. In this case, when the sukuk is issued, the option to subscribe to the sukuk through a mobile platform could be made possible and the retail investors who could be the immediate beneficiaries of the project could lend their surplus money to the government for a fixed period where the government is expected to return the principal amount lent through periodic payments and since the profit portion is not expected as return by the sukuk holders in this proposed structure, considering the contribution made by the sukuk holders, each sukuk holders will have a common benefit of obtaining free services from the hospital developed using sukuk money perpetually as long as the hospital remains. Therefore, in this proposed structure, the incentive to make the investment by the retail sukuk holders rest with the fact that they can be the primary beneficiaries of the project developed by the government using the proposed sukuk. This type of sukuk structure will revive the communal social sentiments to help each other in promoting good which is aligned with the Qur'anic ayath 5:2 where it is stated that: "... and cooperate in righteousness and piety, but do not cooperate in sin and aggression...". Sukuk owners are not only motivated by financial returns; rather, they are also motivated by the delivery of sustainable social outcomes and philanthropic objectives over the long run (Shukri et al., 2019).

Muneeza (2020) pointed out that in certain other jurisdictions, such as Indonesia, the government has established an SPV for local sovereign sukuk issuances that will be utilized for numerous transactions, issuing sukuk directly or through the Sukuk Negara Issuing Company/Perusahaan Penerbit SBSN, which acts as the SPV (Article 6, Law no 19/2008).

In summary the steps of the proposed sukuk structure will be as follows (see Figure 1):

1. Government identifies suitable social project which could originate from a partnership from corporation.

2. After identifying and deciding, the project will be transferred to SPV which is specifically formed for sukuk issuance.

3. The sukuk will be issued by SPV based on qard and perpetual waqf concept.

4. Subscription of the sukuk takes place via mobile platform.

5. Sukuk proceed will be received and certificates are issued.

6. Sukuk proceed transferred by the SPV to the management company of the project.

7. Project successfully finishes.

8. Government will return the principal invested by the sukuk holders, but the relationship does not end as they have formed a perpetual waqf relationship via sukuk to the project.

9. As long as the project remains, the sukuk holders will receive free service or a benefit from the project making them perpetual waqf sukuk holders for the project.

International Journal of Management and Applied Research, 2021, Vol. 8, No. 2 
Figure 1: Proposed Waqf Mobile Sukuk

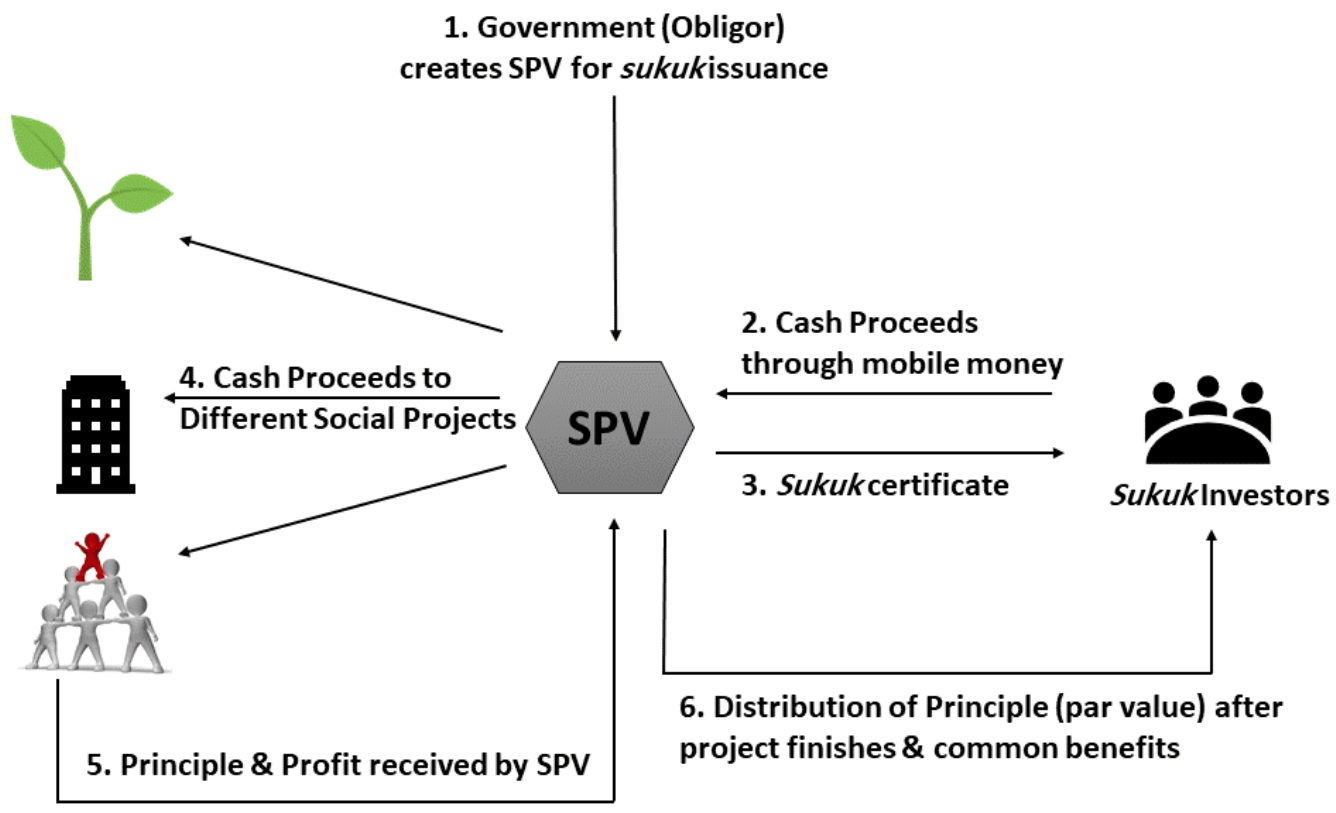

Source: Author's Own Work

In the secondary market, if the sukuk holders want to sell the sukuk, it can only be sold at par, and the transaction can take place before the issuer pays back the principal amount invested. However, after the amount is redeemed, it would be impossible to sell the common service or benefit to be received by all sukuk holders.

Mobile sukuk could make Islamic bond accessible at affordable costs to all individuals, empowering the financially disadvantaged groups. The money raised from the sukuk will be used for funding different development projects, thus through this, low-income retail investors will participate in community development and empowerment via a shari'ah compliant instrument.

\subsection{Targeted Investors}

Sub-Saharan Africa has great potential for mobile sukuk for two main reasons: firstly as a region with a third of Africa's Muslim population, they are actively looking at Islamic finance as viable methods of raising capital at home. Another significant reason is Sub-Saharan Africa being home to all 10 economies worldwide where more adults have a mobile money account than have a financial institution account (Demirguc-Kunt et al., 2018; Piper, 2020; Riley and Kulathunga, 2017). According to Demirguc-Kunt et al (2018), mobile money accounts are very popular in Kenya, where $73 \%$ of individuals in Kenya have at least one mobile money accounts whereas approximately $50 \%$ of individuals in Uganda and Zimbabwe do.

"In 2014 mobile money accounts were concentrated largely in East Africa. Now these accounts have spread to West Africa and beyond. In West Africa, the share of adults owning a mobile money account has risen to about 33 percent in Burkina Faso, Côte d'Ivoire, and Senegal-and to 39 percent in Ghana. And it has reached 
nearly 45 percent in both Gabon and Namibia." (Demirguc-Kunt et. al., 2018, p. 20)

Through this sukuk Sub-Saharan retail, low-income investors will contribute to community development, economic growth, as well as they can contribute in waqf aiming to receive blessing from Allah through funding different social development projects continuously without losing initial investment, and earning common benefits or services, this is how the sukuk is unique.

\subsection{Challenges}

There is a growing awareness that financial inclusion can drive positive outcomes for individuals, the whole society and the wider economy. However, several regulatory questions need to be addressed - consumer protection (How the mobile sukuk promote consumer protection and enhance financial literacy?), credit history (How to address the absence of credit history of the potential investors in the Sub-Saharan Africa?), supervision (How should mobile financial services be supervised and regulated?), etc. Issues related to poor disclosure of transaction cost as well as the cost of accessing Value Added Services via unstructured supplementary service data (USSD) (Riley and Kulathunga, 2017) could affect consumers loyalty. Henceforth, the legal documents of the mobile sukuk structure need to be proposed using basic and understandable language to increase transparency and disclosure, in addition to counter terrorism, KYC (Know Your Customer) and anti-money laundering (AML) compliance. Failure to recognize the complexity of the contract signed, making it probable for them to face extra services fee. This also includes educating the marginalized and potential investors with the necessary financial know-how.

As mentioned in Innovation in Financial Inclusion: Revenue Growth Through Innovative Inclusion of (EY, 2017), creativity is needed to address the absence of credit history of the potential investors in Sub-Saharan Africa where most of them are the financially excluded individuals with no financial track record nor do they necessarily have entrée to proven identity and security details. The M-PESA money platform in Kenya is an exemplar of an open-minded regulatory approach that transforms poor people's lives (Riley and Kulathunga, 2017). The regulators in Kenya realised that they could neither formally license not directly regulate non-banking institutions and thus issued a letter of no objection with conditions for consumer protection and prevention of money laundering. Such open-minded approach might be suitable for other emerging markets in Sub-Saharan Africa given the fast-evolving nature of technological innovation. Therefore, understanding the operational risks arising from the new innovations and instruments is a laborious task for regulators.

\section{Conclusion}

"Social impact investment is nascent in the Middle East and North African region, although a shortage of financial intermediaries coupled with lack of awareness is hindering the growth of this market. Islamic finance was seen as vital for developing the social impact investing market in this region. The principles of Islamic finance overlap with those of social impact investing." (OECD, 2020: 27)

International Journal of Management and Applied Research, 2021, Vol. 8, No. 2 
Conceptually, sukuk is an alternative Islamic finance instrument against conventional bond. Official aid on its own is not satisfactory for funding efforts to fast-track economic growth and improving poverty condition and other Millennium Development Goals (MDGs) in Africa (Ketkar and Ratha, 2009). In the absence of inclusive investment mechanisms in Sub-Saharan Africa, 26 percent of adults across the Sub-Saharan Africa region reported still relying on informal way of saving (Demirguc-Kunt et al., 2018). There is a need for innovative financing tools which will fuel up the economic growth and which will be self-sufficient too. This proposed waqf mobile sukuk could facilitate communal development spirit. Returns on social investment include both economic and social benefits which is what the proposed waqf mobile sukuk aims for. Despite the possibility of not meeting its objective, waqf mobile sukuk can be regarded as the first mobile shari'ah compliant instrument to be offered in Sub-Saharan Africa with a focus on waqf and social development. Though there is a possibility that the first trial and launch will not provide the desired results, there are substantial chances to set an example by improving the product in this geographic region and replicating it elsewhere with similar features and potential.

\section{References}

1. Adnan Khurshid, M., Al-Aali, A., Ali Soliman, A. and Mohamad Amin, S. (2014), "Developing an Islamic corporate social responsibility model (ICSR)", Competitiveness Review, Vol. 24 No. 4, pp. 258-274. https://doi.org/10.1108/CR01-2013-0004

2. Agha, E. (2018), "How Islamic finance can help the government of Pakistan to solve its water and electricity crisis: a proposed model of waqf-sukuk", Islamic Finance Review ISFIRE, Vol. 9, No. 5, pp. 92-97.

3. Aker, J. C. and Mbiti, I. M. (2010), "Mobile Phones and Economic Development in Africa" Journal of Economic Perspectives, Vol. 24, No. 3, pp. 207-32. https://doi.org/10.1257/jep.24.3.207

4. Bacha, O. I. and Mirakhor, A. (2013), Islamic Capital Markets: A Comperative Approach. Singapore: Wiley. https://doi.org/10.1002/9781118465158

5. Blumenstock, J.E.; Eagle, N. and Fafchamps, M. (2016), "Airtime transfers and mobile communications: Evidence in the aftermath of natural disasters", Journal of Development Economics, Vol. 120, pp. 157-181. https://doi.org/10.1016/j.jdeveco.2016.01.003

6. Bongomin, G. O.; Ntayi, J. M., C.; Munene, J., and Malinga, C. A. (2018), "Mobile Money and Financial Inclusion in Sub Saharan Africa: The Moderating Role of Social Networks", Journal of African Business, Vol. 19, No. 3, pp. 361384. https://doi.org/10.1080/15228916.2017.1416214

7. Bursa Malaysia (2021), Central Depository System. [Online] Available from: https://bursa2u.bursamalaysia.com/Web/Incident/ViewKbArticle.aspx?Id=70360a5 2-94e0-e311-80c0-0050569c236c [Accessed on 7 July 2021].

8. Cook, T. and Osano, E. (2018), "The story of M-Akiba: Selling Kenyan treasury bonds via mobile", FSD Kenya [Online] Available from: https://fsdkenya.org/blog/the-story-of-m-akiba-selling-kenyan-treasury-bonds-viamobile/[Accessed on 7 July 2021].

International Journal of Management and Applied Research, 2021, Vol. 8, No. 2 
9. Dadush, S. (2015), "Regulating Social Finance: Can Social Stock Exchange Meet the Challenge", University of Pennsylvania Journal of International Law, Vol. 37, No. 1, pp. 139-230.

10. Demirguc-Kunt, A.; Klapper, L.; Singer, D.; Ansar, S.; and Hess, J. (2018). The Global Findex Database 2017: Measuring Financial Inclusion and the Fintech Revolution. Washington, DC: World Bank.

11. Donner, J. and Tellez, C. A. (2008), "Mobile banking and economic development: Linking adoption, impact and use", Asian Journal of Communication, Vol. 18, No. 4, pp. 318-322. https://doi.org/10.1080/01292980802344190

12. Donovan, K. (2012), "Mobile Money for Financial Inclusion”, in: Information and Communications for Development, pp. 61-73. https://doi.org/10.1596/9780821389911_ch04

13. Ernst \& Young (EY) (2017), Innovation in Financial Inclusion: Revenue Growth Through Innovative Inclusion. EY Publication.

14. Farook, S.; Hassan, M. K. and Lanis , R. (2011), "Determinants of corporate social responsibility disclosure: the case of Islamic banks", Journal of Islamic Accounting and Business Research, Vol. 2, No. 2, pp. 114-141. https://doi.org/10.1108/17590811111170539

15. Haftu, G. G. (2019), "Information communications technology and economic growth in Sub-Saharan Africa: A panel data approach", Telecommunications Policy, Vol. 43, No. 1, pp. 88-99. https://doi.org/10.1016/j.telpol.2018.03.010

16. Hughes, N. and Lonie, S. (2007), "M-Pesa: Mobile Money for the "Unbanked" Turning Cell Phones into 24-h tellers in Kenya", Innovations: Technology, Governance, Globalization, Vol. 2, No. 1-2, pp. 63-81. https://doi.org/10.1162/itgg.2007.2.1-2.63

17. Jack, W. and Suri, T. (2014), "Risk sharing and transactions costs: evidence from Kenya's mobile money revolution", American Economic Review, Vol. 104, No. 1, pp. 183-223. https://doi.org/10.1257/aer.104.1.183

18. Kacungira, N. (2017), Kenya Starts Selling Bonds via Mobile Phones. Nairobi: BBC News [Online] Available from: https://www.bbc.co.uk/news/business39364885 [Accessed on 2 July 2021].

19. Ketkar, S. and Ratha, D. (2009). Innovative Financing for Development, Washington DC: The World Bank.

20. Klapper, L. and Singer, D. (2014), The Opportunities of Digitizing Payments, Washington: The World Bank. [Online] Available from: http://documents.worldbank.org/curated/en/188451468336589650/The-opportunities-ofdigitizing-payments [Accessed 2 July 2020].

21. Klapper, L. and Singer, D. (2017), "The Opportunities and Challenges of Digitizing Government-to- Person Payments", World Bank Research Observer, Vol. 32, No. 2, pp. 211-226. https://doi.org/10.1093/wbro/lkx003

22. M-Akiba. (2017), Save Money. Make Money. Build Kenya. [Online] Available from: http://www.m-akiba.go.ke/index.php/about-m-akiba [Accessed on 2 July 2021].

International Journal of Management and Applied Research, 2021, Vol. 8, No. 2 
23. Mar Iman, M. G. and Mohammed, M. O. (2020), "Animal Waqf as a Thrust of Social Entrepreneurship", International Journal of Management and Applied Research, Vol. 7, No. 4, pp. 411-431. https://doi.org/10.18646/2056.74.20-030

24. Mohsin, M. M. A. (2019), "Waqfintech and Sustainable Socio-Economic Development", International Journal of Management and Applied Research, Vol. 6, No. 3, pp. 130-141. https://doi.org/10.18646/2056.63.19-009

25. Muflih, M. (2021), "The link between corporate social responsibility and customer loyalty: Empirical evidence from the Islamic banking industry", Journal of Retailing and Consumer Services, Vol. 61, 102558, https://doi.org/10.1016/j.jretconser.2021.102558

26. Muneeza, A. (2020), "Short-term Sharī'ah-compliant Islamic liquidity management instruments to sustain Islamic banking The case of Maldives", Journal of Islamic Accounting and Business Research, Vol. 11, No. 2, pp. 428-439. https://doi.org/10.1108/JIABR-04-2018-0055

27. OECD (2020), How Islamic finance contributes to achieving the Sustainable Development Goals , Paris: Organisation for Economic Cooperation and Development (OECD). https://doi.org/10.1787/24140929

28. Piper, K. (2020), "What Kenya can teach its neighbors and the US about improving the lives of the unbanked", Vox, Available from: https://www.vox.com/futureperfect/21420357/kenya-mobile-banking-unbanked-cellphone-money [21 Sept 2020].

29. Riley, T. A. and Kulathunga, A. (2017), Bringing E-money to the Poor: Successes and Failures, Washington DC: World Bank Publications, https://doi.org/10.1596/978-1-4648-0462-5

30. Schulze, L. (2014), "The three billion new middle-class opportunity: The successes and technical challenges of mobile financial services in emerging market", Journal of Payments Strategy \& Systems, Vol. 8, No. 3, pp. 235-245.

31. Shaikh, S. A.; Ismail, A. G., and Shafiai, M. H. (2017). Application of waqf for social and development finance. ISRA International Journal of Islamic Finance, Vol. 9, No. 1, pp. 5-14. https://doi.org/10.1108/IJIF-07-2017-002

32. Shukri, N.; Zamri, S.; Muneeza, A. and Ghulam, H. (2019), "Waqf Development in Marawi City via Issuance of Perpetual Waqf Sukuk", International Journal of Management and Applied Research, Vol. 6, No. 2, pp. 68-80. https://doi.org/10.18646/2056.62.19-005

33. Sy, A. N. ; Maino, R. ; Massara, A. ; Perez-Saiz, H.; Sharma, P. (2019), FinTech in Sub-Saharan African Countries: A Game Changer?, Washington: International Monetary Fund. https://doi.org/10.5089/9781484385661.087

34. Tan, V. (2018), "Indonesian Millennials Snap Up State Sukuk as Government Opens Digital Sales Channel”, IFN FinTech Huddle Report 2018, p. 24.

35. Van Hove, L. and Dubus, A. (2019), "M-PESA and Financial Inclusion in Kenya: Of Paying Comes Saving?", Sustainability, Vol. 11, No. 3, 568. https://doi.org/10.3390/su11030568

International Journal of Management and Applied Research, 2021, Vol. 8, No. 2 
Islamic Capital Market for Social Development: Innovating Waqf Mobile Sukuk in SubSaharan Africa

36. The World Bank Group (2021), Financial Inclusion [Online] Available from: https://www.worldbank.org/en/topic/financialinclusion/overview [Accessed 2 July 2020].

International Journal of Management and Applied Research, 2021, Vol. 8, No. 2 